\title{
An Examination Of The Impact Of Team Teaching On Student Learning Outcomes And Student Satisfaction In Undergraduate Business Capstone Courses
}

Michael Colburn, Ph.D., Ashland University, USA

Daniel Sullivan, Ed.D., J.D., Ashland University, USA

Daniel E. Fox, J.D., C.P.A., Ashland University, USA

\begin{abstract}
This study examines the impact of team teaching on student learning outcomes and student satisfaction in the context of three undergraduate business capstone courses. Students in three undergraduate business capstone course sections were selected for the study. One section of the capstone course was taught using a team delivery model and the other two sections were taught by a single faculty member. The study found that students' GPA had a significant correlation with their performance in the team taught course. The data suggests that students with a GPA of less than 3.28 in the team taught course, performed higher than would be expected. Moreover their individual performance scores appeared to be higher than the regression line would predict. Students in the team taught course also were satisfied with the team teaching method.
\end{abstract}

Keywords: Team Teaching; Learning Outcomes

\section{INTRODUCTION}

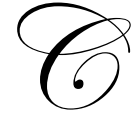

olleges and universities face two important challenges; curricular relevance and the critical priority of information provided to students (AACSB, 2002). One way institutions can meet these challenges is to leverage the strengths of their faculty resources and adopt a team teaching approach to delivering classroom instruction. According to Gayton (2010), team teaching produces several benefits that enhance the learning experience. Among these include the development of dynamic curriculum, interactive learning environments, and critical internal and cross discipline thinking.

A team teaching approach marks a distinct break from traditional isolationist academic practices of the past (Lester and Evans, 2009). Although team teaching is not a new concept, it has found new relevance in today's global economy (Durud, 2010). This complex and constantly changing environment makes it necessary for instructors to blur the lines between educational disciplines to maximize student outcomes (Gaytan, 2010). Graduates must possess the ability to process and interpret complex multidiscipline data. This means that the end product of a successful educational experience must be information rich graduates who can effectively apply proven academic theories in this diversified environment. (Borrelli, Cerny-Koenig, Pearson-Mims, Williams, Johnson, and Perillo, 2010). To achieve this result, faculty must break with tradition and find innovative ways to achieve enlightenment (Sullivan, 1994). Collaborative teaching achieves this object by enhancing the learning environment for students and faculty alike (Lester and Evans, 2009).

\section{Approaches to Team teaching}

In higher education, team teaching has taken different forms. One of the most common forms involves the mixing the curricula from two or more different courses in an effort to provide the student with an enhanced learning experience. Studies in this area provide a structure for interdisciplinary team teaching (Shipley, 2006; Helms, Alvis, 
and Willis, 2005) and highlight its potential benefits (Beck, 2006). In a 2006 study by Beck, an interdisciplinary team teaching approach was used to combine aeronautical engineering and communications courses in an effort to improve writing and presentation skills among engineering students. The study found that the experience not only benefitted students, but also suggested techniques that faculty could use to improve planning and coordination among team members. In another study, Helms, Alvis, and Willis (2005) combined aspects of a manufacturing applications course, specifically operations process and manufacturing strategies, with finance and accounting to increase students' knowledge of the impact of manufacturing decisions on business performance. Their study found that students and faculty benefited from the experience. Students were better able to interconnect key interdisciplinary concepts and witness the benefits of cooperation, team building, and communications through the instructors' behavior. Faculty members were able to avoid redundancy and lay the foundation for interdisciplinary scholarship.

Another commonly used form of team teaching emphasizes the co-facilitation of a single subject matter in an effort to improve teaching skills, provide students with a new and different learning experience, and as a way to promote professional growth (Cohen and DeLois, 2001). This technique enables instructors to exploit each other's strengths in the area of study for the benefit of the students and improve their own understanding of the topic. Team teaching of this type provides a forum for faculty to learn from each other (Evans, 2009).

Whatever the form, three distinct models of team teaching are present in the literature. They are the interactive, participant-observer, and the rotational models (White, Henley, \& Brabston, 1998). In the interactive team teaching model, two instructors present course material concurrently. Each share the attention of the class and each engages in debates over the information presented by his colleague. In its purest form, interactive team teaching activities are planned, executed, and evaluated by all team members (Brookfield, 2006; Helms, Alvis, and Willis, 2005). The participant observer model requires both instructors to be present in the classroom, but only one instructor presents the material on a given topic. This method provides the opportunity for debate on topics in question and preserves the autonomy of the instructor in the eyes of the students. The non-active team member or observing member's presence signals to students the unity of instruction. Open debate on the topic of the day occurs only if students take the initiative to draw the observing instructor into the discussion (Flanagan \& Ralston, 1983). Unlike the interactive and participant-observer team teaching models, the rotational team teaching model does not require instructors to share the classroom. Individual instructors rotate through the classroom attending only those classes they are assigned to teach. This model is most similar to the traditional single course single instructor teaching model. It preserves instructor independence, eliminating the debate created when instructors of differing opinion share the classroom (Helms, Alvis, and Willis, 2005). Some experts also refer to this type of model as "serial" team teaching because the end result is often a series of mini courses combined under the umbrella of a single general course description (Davis, 1995).

Davis (1995) stated that the fundamentals of team teaching are simple concepts known to all educators; planning, content integration, teaching, and evaluation. These concepts though easy to understand in a singular context become complicated in a team teaching environment. According to Davis, interdisciplinary team teaching consisted of all four of these components while interdisciplinary team teaching consists only of planning, teaching, and evaluation. The key to success hinges on the degree of collaboration reach team member is willing to contribute to the team teaching experience. Many experts agree that faculty collaboration must be present in any successful team teaching effort (Nevin, Thousand, \& Villa, 2009; Dyrud, 2010; Helms, Alvis, and Willis, 2005; Dugan and Letterman, 2008). Essential to this process is the willingness to participate in extensive planning on course material and classroom design. Equally important the process is communication skills. Communication channels must remain open at all times during the process to ensure the even presentation of material. Lastly, team teaching requires tolerance and a willingness to appreciate different opinions and perspectives among acknowledged subject matter experts (Lester and Evans, 2009). When all of these components successfully combine together, colleges and universities achieve the curricular relevance and the critical priority of information needed to make the team teaching a relevant student experience.

Much of the literature relates to various team teaching models and faculty challenges in working together. Very few articles have focused specifically on student performance as a result of the various team teaching models. This paper will focus in team teaching and its impact on student learning outcomes. 


\section{RESEARCH QUESTIONS}

This study examines the impact of team teaching on student learning outcomes and student satisfaction in undergraduate business capstone courses. The authors posed the following research questions:

1. What is the impact of team teaching in an undergraduate senior capstone course on student learning and student satisfaction?

2. What are the explanatory variables that may influence student learning and satisfaction?

\section{DATA SAMPLE}

Data were collected from students in three sections of undergraduate business capstone courses. The team taught course (Designated as Section B) was taught using a three person team teaching model. The other two sections were non team taught (Designated as Sections $\mathrm{A}$ and $\mathrm{X}$ ) by a single faculty member, using the individual faculty teaching approach. Of the 69 students across all three sections, 50 chose to participate in the study.

\section{METHODOLOGY}

Following are the data collected on selected student and faculty outcomes:

\begin{tabular}{|c|c|}
\hline Response Variables & Explanatory Variables \\
\hline Student Outcomes: & \multirow{7}{*}{$\begin{array}{cl}\text { Students: } & \\
\circ & \text { GPA } \\
\circ & \text { Major } \\
\circ & \text { Gender } \\
\circ & \text { Previous experience with team-taught classes } \\
\circ & \text { Previous experience with the use of technology in } \\
& \text { learning }\end{array}$} \\
\hline \multirow{3}{*}{$\begin{array}{l}\text { Student performance on tests measuring student } \\
\text { comprehension of key course content. This included } \\
\text { quizzes and pre and post tests }\end{array}$} & \\
\hline & \\
\hline & \\
\hline \multirow{5}{*}{$\begin{array}{l}\text { Student performance on case analyses to assess } \\
\text { student learning outcome of critical thinking skills. } \\
\text { Student satisfaction through the analysis of the } \\
\text { student survey and responses to open ended } \\
\text { questions. }\end{array}$} & \\
\hline & \\
\hline & \\
\hline & Faculty: \\
\hline & jith team \\
\hline \multicolumn{2}{|l|}{ Faculty Outcomes: } \\
\hline $\begin{array}{l}\text { Faculty satisfaction through the analyses of responses } \\
\text { in in-depth interviews at the conclusion of the course }\end{array}$ & \\
\hline
\end{tabular}

Students in the team taught (Section B) completed a questionnaire asking for feedback on their reaction to this team teaching experience. Students were asked to rate their experience on a scale of 1 (Strongly Disagree) to 5 (Strongly Agree) to the following statements:

\begin{tabular}{|l|}
\hline Team Teaching Aspects \\
\hline Teaching was well coordinated among the faculty team members. \\
\hline The material covered by the different faculty team members was well integrated. \\
\hline The course continuity among the faculty team members was effective \\
\hline Team teaching provided me with diverse insights into the course content. \\
\hline The team teaching method provided me with a valuable learning experience. \\
\hline The course technology helped me better prepare \& understand the course material. \\
\hline
\end{tabular}

Students were asked to rate their experience on a scale of 0 (Low) and 10 (High) to the following questions:

\begin{tabular}{|l|}
\hline Course \\
\hline How would you rate this course? \\
\hline Would you recommend the team taught method for this course? \\
\hline
\end{tabular}


All data collection instruments were the same across all three sections. Students were given the option to: provide/not to provide their GPA; provide/not provide information on previous experience with team taught courses and the use of technology in the classroom; complete/not complete the learning style instrument; and to complete/not complete the student satisfaction questionnaire administered at the end of the course. This information forms (whether completed or not) were put in sealed envelopes by each student and given to an administrative assistant to hold until all course grades were entered. The faculty team did not know which students chose to participate, or their responses to the various questionnaire and instruments until all grades had been posted.

\section{Course Design and Implementation}

The faculty for this study chose to use highly collaborative approach in designing and delivering the team taught course. There were a number of work sessions to design the learning activities and determine what faculty member would take the lead in the various course topics. The faculty agreed on a common lesson plan format, assessment methodology and grading criteria. Each member of the faculty team reviewed all of the lesson plans and provided feedback and suggestions to each other. Faculty agreed each would attend all class sessions for the first two weeks of the course to introduce the faculty team to the students. Because of the high collaboration on the course design and the transition exercises design from one learning module to the other, faculty team member attendance was optional when another faculty member was the lead for a particular class.

\section{RESEARCH RESULTS}

\section{Student Learning Outcomes}

Graph 1 is a box plot of each class section performance on individual assignments. This includes points earned on tests, case analyses, class assignments and attendance.

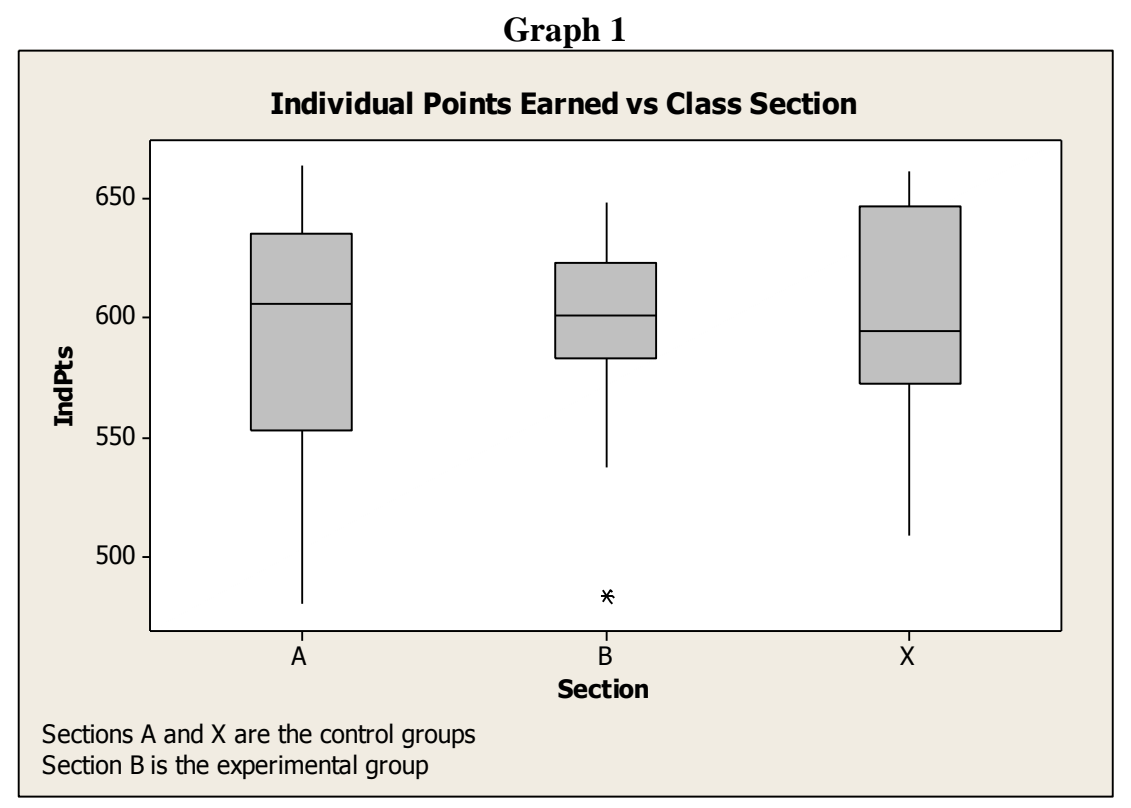

Class sections $\mathrm{A}$ and $\mathrm{X}$ were the control groups and class section $\mathrm{B}$ was the experimental group. The median class section individual points earned were close in value (Section A was 606, Section B was 600, Section X was 594). The variation, as measured by the inner quartile range, was lower for Section $B(I Q R=40)$ when compared with Section A $(\mathrm{IQR}=79)$ and Section $X(I Q R=72)$. At first inspection it appeared that there was no improvement in the performance for the experimental group compared with the control groups. However, there was a reduced variation in performance among the students in the experimental group. 
The performance data was further analyzed to investigate whether other variables had an impact on student learning outcomes. There was no significant impact in relation to the variables of gender, major, or learning style on student performance of individual assignments. Analysis did discover, however, that students' cumulative GPA had a significant correlation with their performance. Graph 2 is a box plot of each class section's GPA

\section{Graph 2}

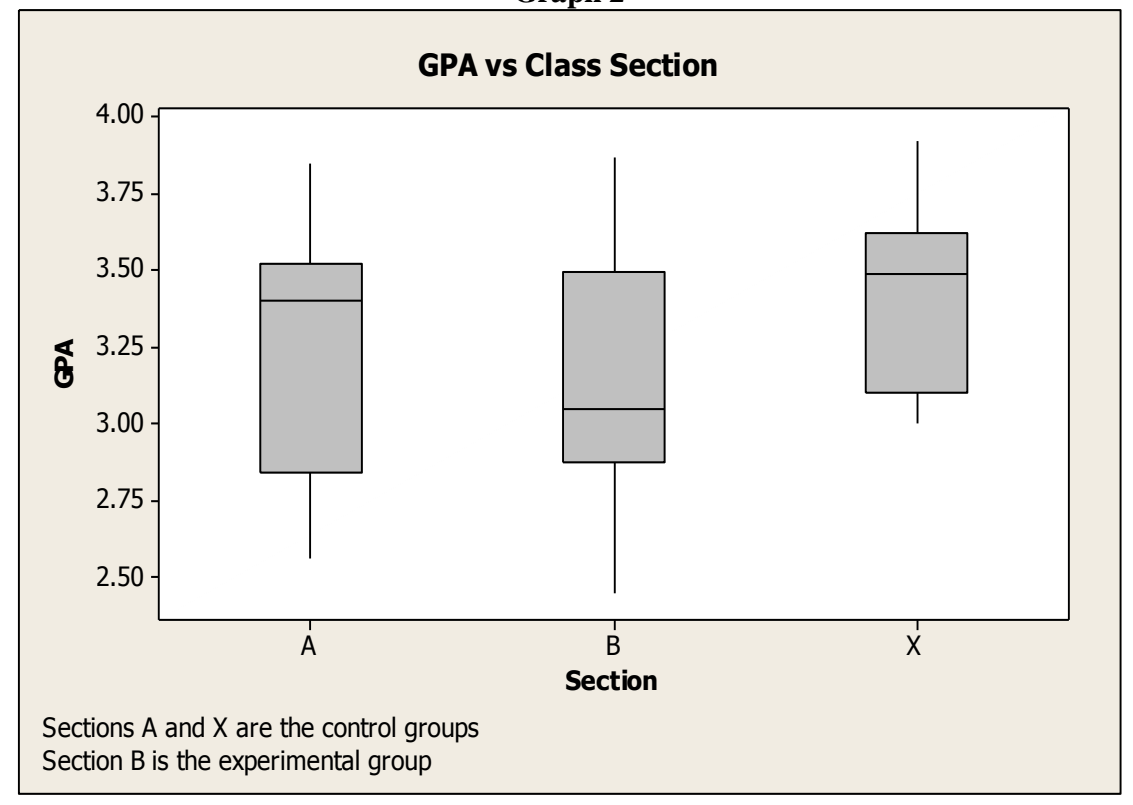

The median GPA for Section A was 3.40. The median GPA for Section B was 3.05. The median GPA for Section X was 3.49.

We then ran a regression analysis to determine if there was a statistically significant relationship between GPA and student performance on individual assignments. Graph 31 shows the regression line for this analysis.

\section{Graph 3}

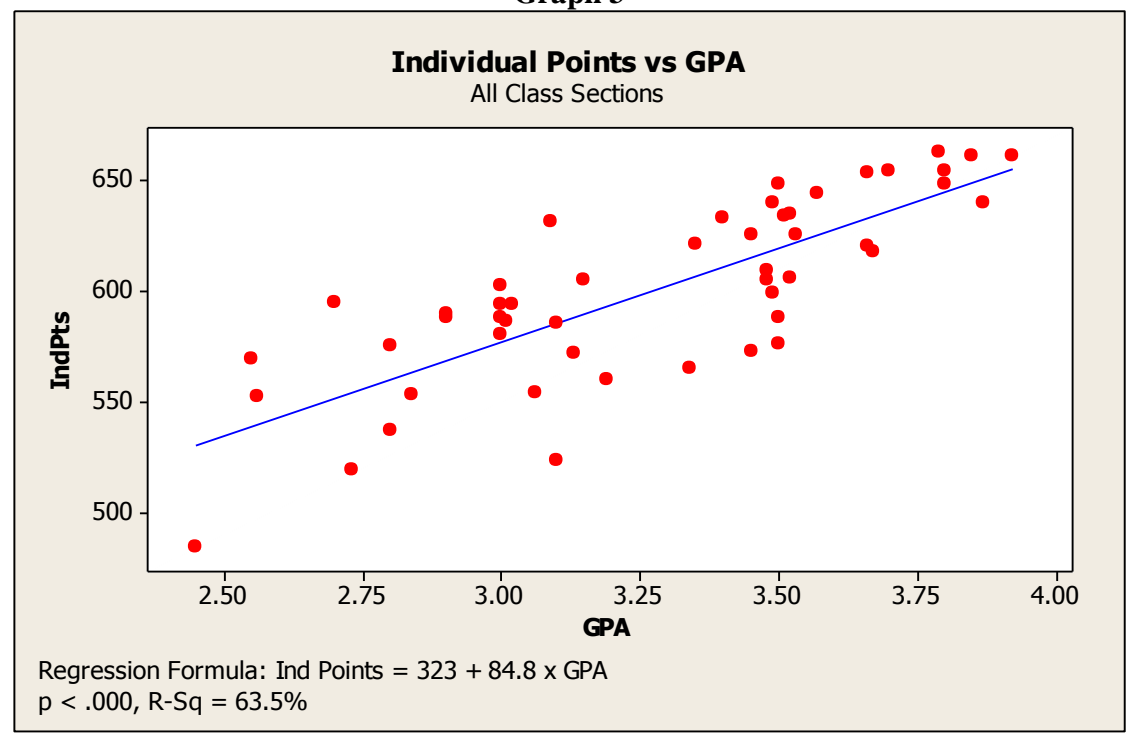


Graph 4 shows the same data as Graph 3, but also identifies the individual class sections.

Graph 4

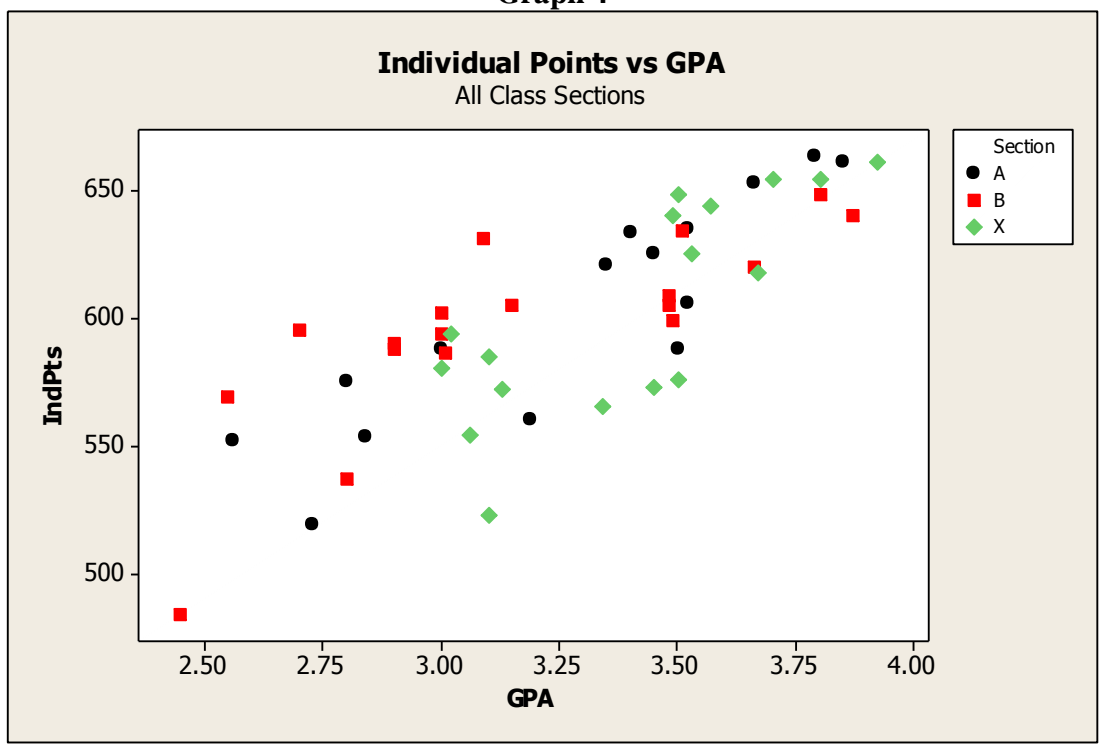

The data suggests that students with lower GPAs in Section B (experimental group) performed higher than would be expected. More of their individual performance scores appear to be higher than the regression line would predict. To test this hypothesis, the data was adjusted to take out the impact of GPA. This adjustment was made by using the following formula:

Adjusted Individual Points = Individual Points $+(3.28-$ GPA) $x 84.8$, where 3.28 was the average GPA for all students and 84.8 was the coefficient representing the impact of GPA on student performance.

Graph 5 shows this adjustment.

Graph 5

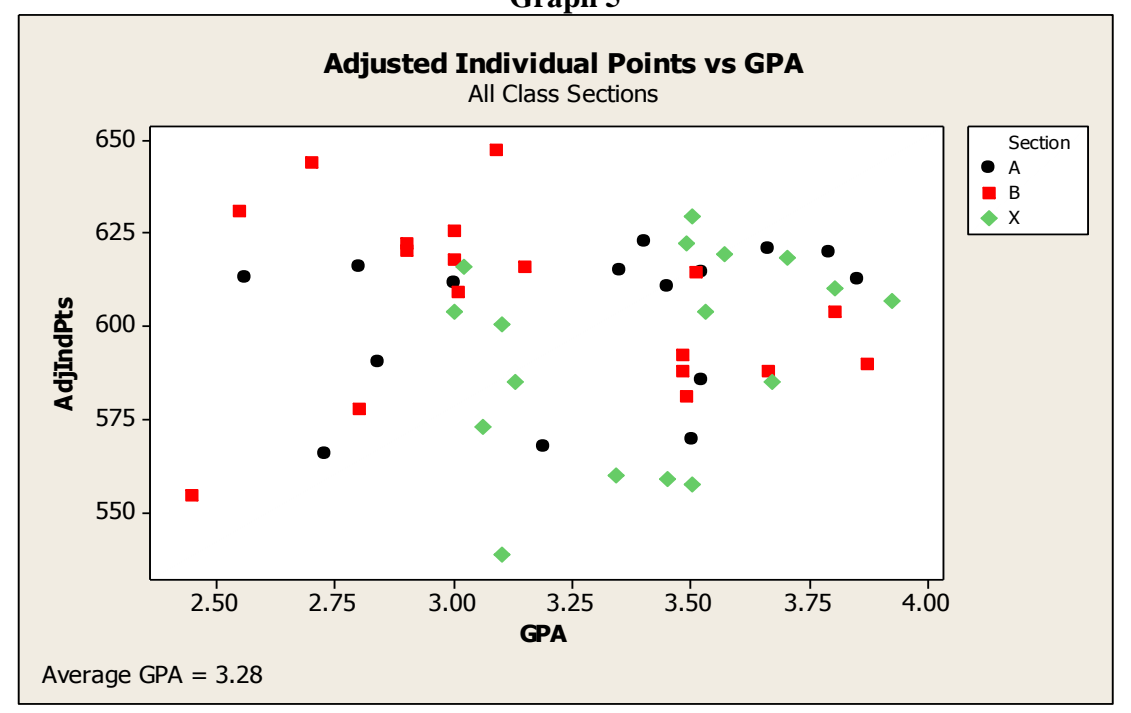


Using the " $t$ " test, we tested for the difference of means for the experimental group (Section B) versus the control group (Sections A and X combined). We ran a test for scores (adjusted individual points) for students with GPAs less than 3.28. Chart 1 shows the results of this test.

\section{Chart 1 - "t" test for difference of means for students with a GPA less than 3.28}

\begin{tabular}{|c|c|c|c|c|}
\hline $\begin{array}{c}\text { Section B Mean Adjusted } \\
\text { Individual Points (n) }\end{array}$ & $\begin{array}{c}\text { Sections AX Mean Adjusted } \\
\text { Individual Points (n) }\end{array}$ & $\begin{array}{c}\text { Standard } \\
\text { Deviation }\end{array}$ & " $\mathrm{t}$ " & $\mathrm{P}$ \\
\hline $615(11)$ & $590(12)$ & 10.85 & 2.31 & .017 \\
\hline
\end{tabular}

There is a statistically significant difference between Section B and Sections A and X on Mean Adjusted Individual Points, suggesting that the team teaching model had an impact on students who had a GPA of less than 3.28. There was no significant difference in performance for students who had a GPA of greater than 3.28.

We also analyzed student performance for two subsections of individual performance after adjusted for GPA on case analyses (four case studies) and (2) students' performance on tests (eight quizzes and one final exam). Chart 2 shows the results for case analysis performance. Chart 3 shows the results for test performance.

Chart 2 - " $t$ " test for difference of means for students with a GPA less than 3.28

\begin{tabular}{|c|c|c|c|c|}
\hline $\begin{array}{c}\text { Section B Mean Adjusted } \\
\text { Case Analysis Points (n) }\end{array}$ & $\begin{array}{c}\text { Sections AX Mean Adjusted Case } \\
\text { Analysis Points (n) }\end{array}$ & $\begin{array}{c}\text { Standard } \\
\text { Deviation }\end{array}$ & " $\mathrm{t}$ " & $\mathrm{P}$ \\
\hline $402(11)$ & $375(12)$ & 12.18 & 2.26 & .019 \\
\hline
\end{tabular}

Chart 3 - "t" test for difference of means for students with a GPA less than 3.28

\begin{tabular}{|c|c|c|c|c|}
\hline $\begin{array}{c}\text { Section B Mean Adjusted } \\
\text { Test Points (n) }\end{array}$ & $\begin{array}{c}\text { Sections AX Mean Adjusted Test } \\
\text { Points (n) }\end{array}$ & $\begin{array}{c}\text { Standard } \\
\text { Deviation }\end{array}$ & "t" & P \\
\hline $180(11)$ & $171(12)$ & 5.60 & 1.58 & .068 \\
\hline
\end{tabular}

There was a statistically significant difference on case analysis performance for students with GPAs less than 3.28. There was not a statistically significant difference, however, on test performance, using $p<.05$ as the basis.

\section{STUDENT SATISFACTION}

Students in the Experimental Group (Section B) completed a questionnaire asking them for feedback on their reaction to this team teaching experience. Following is a summary of their feedback:

Student Ratings on a scale of 1 (Strongly Disagree) to 5 (Strongly Agree)

\begin{tabular}{|l|l|}
\hline Rating & Team Teaching Aspects \\
\hline 4.05 & Teaching was well coordinated among the faculty team members. \\
\hline 4.47 & The material covered by the different faculty team members was well integrated. \\
\hline 4.05 & The course continuity among the faculty team members was effective \\
\hline 4.74 & Team teaching provided me with diverse insights into the course content. \\
\hline 4.42 & The team teaching method provided me with a valuable learning experience. \\
\hline 3.53 & The course technology helped me better prepare \& understand the course material. \\
\hline
\end{tabular}

Students overall rating of the course and the team teaching method on a scale of 0 (Low) and 10 (High)

\begin{tabular}{|l|l|}
\hline Rating & Course \\
\hline 7.72 & How would you rate this course? \\
\hline 8.89 & Would you recommend the team taught method for this course? \\
\hline
\end{tabular}


From the above results, students in the team taught course were overall pleased with the team teaching method. In the students' response to what worked well for them in the team taught course, they liked the different perspectives, expertise and experiences of the faculty team members.

Each member of the faculty team was interviewed by a professor from the university's College of Education. The analysis of these interviews indicated high faculty satisfaction in the team teaching method. The faculty members were highly motivated to improve the undergraduate student experience, enjoyed the collegiality in the design and implementation of the course, and exhibited skill in negotiating win-win solutions when there were differences. Although attendance in many of the class sessions was optional, the faculty team members frequently attended classes that were facilitated by other members of the team. The faculty team found this optional attendance as a time investment in their professional development.

\section{CONCLUSIONS AND RECOMMENDATIONS}

In analyzing the data, students' gender, major, and learning style showed no significant correlation to student performance on individual assignments within any of the class sections taught. The authors did find, however, that students' GPA had a significant correlation with their performance in the team taught course. The data suggests that students with a GPA of less than 3.28 in the team taught course, performed higher than would be expected. More of their individual performance scores appeared to be higher than the regression line would predict. There was no significant difference in performance for students who had a GPA of greater than 3.28. Students and faculty in the team taught course were satisfied with the team teaching method.

This study suggests that team teaching may help students with lower GPAs improve their performance on individual assignments in a course. Based on the limited number students in the study, more research is needed to confirm this result. The authors also believe that further study needs to be done to determine why the team teaching model would impact students with lower GPAs performance on individual assignments.

\section{AUTHOR INFORMATION}

Dr. Michael Colburn is an Assistant Professor of Management at Ashland University teaching in the BSBS and MBA programs. He earned Ph.D. from The Ohio State University with a major in adult education and minors in human resource management and organizational communication. Dr. Colburn is also a registered professional engineer in the State of Ohio. He teaches courses in strategic management, organization development and operations management. He has presented recently at the Midwest Decision Sciences Conference and at the Job Shop Lean Conference at The Ohio State University. Dr. Colburn was awarded the Meritorious Service Citation by Ohio State's College of Engineering in 2004. He was inducted in the Glo-Bus (business simulation) Hall of Fame in 2010. Dr. Colburn consults with a wide range of companies. E-mail: mcolburn@ashland.edu.

Dr. Daniel Sullivan is an Assistant Professor of Management/Entrepreneurship at Ashland University's Richard E. \& Sandra J. Dauch College of Business \& Economics. He holds an Economics degree from the University of Pittsburgh, an MBA from Indiana University of Pennsylvania, a J.D. from the University of Akron, and an Ed.D. in Organizational Leadership from Ashland University. He is an experienced business professional working 33 years in private industry. During this time, he held leadership positions in manufacturing, operations management, quality assurance, and labor negotiations. E-mail: dsulli1 @ashland.edu. Corresponding author.

Dr. Daniel Fox is an Associate Professor of Law at Ashland University, teaching in the BSBA and MBA Programs. He earned his Jurist Doctorate from The Ohio Northern University College of Law. Dr. Fox is also a Certified Public Accountant and Licensed Practicing Attorney in the State of Ohio. He teaches courses in the area of law, entrepreneurship, accounting and finance. He recently presented at the American Accounting Association Conference, the Lilly Conference, and the Midwest Decision Sciences Conference. He has been published most recently in the Spring 2009 edition of the Journal of Entrepreneurship Education and the March 2009 edition of the International Journal of Business Research. Dr. Fox consulting and law practice is focused on small and startup businesses. E-mail: dfox1@ashland.edu. 


\section{REFERENCES}

1. American Society of Collegiate Schools of Business. (2002, April). Management Education at risk: A report from the Management Education Task Force. Retrieved from http://www.aacsb.edu/publications/metf/METFReport-Executive Summary.pdf

2. Beck, A. (2006). Adventures in team teaching: Integrating communications into an engineering curriculum. Teaching English in a Two Year College, 34(1), 59-70.

3. Borrelli, S., Cerny-Koenig, T., Pearson-Mims, C.H., Williams, K., Johnson, C., \& Perillo, C. (2010, June). Collaborative approach for teaching information literacy in an introductory plant science course. NACATE Journal.

4. $\quad$ Brookfield, S.D. (2006). The skillful teacher: On technique, trust and responsiveness in the classroom ( $2^{\text {nd }}$ ed.). San Francisco: Jossey-Bass.

5. Cohen, M.B., \& DeLois, K. (2001). Training in tandem: Co-facilitation and role modeling in group course work. Social Work with Groups, 24(1), 21-36.

6. Davis, J.R. (1995). Interdisciplinary courses and team teaching: New arrangements for learning. Phoenix, AZ: American council on Education and The Onyx Press.

7. Dugan, K., \& Letterman, M. (2008). Student appraisals of collaborative teaching. College Teaching, 56(1), 11-15.

8. Dyrud, M.A. (2010, March). Team teaching, Part 1. Business Communication Quarterly, 73(1), 80-105.

9. Flanagan, M.F., \& Ralston, D.A. (1983). Intra-coordinated team teaching: Benefits for both students and instructors. Teaching of Psychology, 10, 116-117.

10. Gaytan, J. (2010, March). Instructional strategies to accommodate a team-teaching approach. Business Communication Quarterly.

11. Helms, M.M., Alvis, J.M., \& Willis, M. (2005, September/October). Planning and implementing shared team teaching: An MBA team-teaching case study. Journal of Education for Business, 29-34.

12. Lester, J.N.\& Evans K.R. (2009). Instructors' experiences of collaboratively teaching: Building something bigger. International Journal of Teaching and Learning in Higher Education, Vol. 20, \#3, Pgs.373-382.

13. Shibley, I.A., Jr. (2006). Interdisciplinary team teaching: Negotiating pedagogical differences. College Teaching, 54(3), 271-274.

14. Sullivan, P.A. (1994). Revising the myth of the independent scholar. In S.B. Regan, T. fox, \& D. Bleich (Eds.), Writing with: New directions in collaborative teaching, learning, and research (pp.11-29). Albany, NY: State University of New York Press.

15. White, C.S., Henley, J.A., \& Brabston, M.E. (1998). To team teach or no to team teach-that is the question: A faculty perspective. Marketing Education Review, 8(3), 13-23. 


\section{$\underline{\text { NOTES }}$}

